\title{
SPIRITUALITAS KAUM FUNDAMENTALIS
}

\author{
Ahmad Musyafiq \\ IAIN Walisongo Semarang \\ e-mail: ahmadmusyafiq@yahoo.co.id
}

\begin{abstract}
One of the most important phenomenon that characterized the begining of XXI century is the blossom of spiritual activities. Broadly speaking, there are two model of spiritualities: institutional spirituality like tarekat and non-institutional spirituality. This article focus on how religious study that so far executed by Hizbut Tahrir Indonesia Central Java, which much pertained to the main themes of tasawuf study, like purification of heart, tawakkal, ikhlas, sabar, etc. But because they rejected tasawwuf, so they applied the term of spirituality.

$* * *$

Salah satu fenomena terpenting yang yang mencirikan awal abad XXI adalah berkembangnya aktifitas spiritual. Secara luas, ada dua model spiritualitas: spiritualitas institusional seperti tarikat dan spiritualitas non-institusional. Artikel ini memfokuskan pada bagaimana kajian agama yang selama ini dilakukan oleh Hizbut Tahrir Indonesia in central Java yang terkait erat dengan tema-tema utama dalam kajian tasawuf seperti pemurnian hati, tawakkal, ikhlas, sabar, dan lain-lain. Namun karena mereka menolak tasawuf maka mereka mereka menggunakan spiritualitas.
\end{abstract}

Keywords: spiritualitas, fundamentalisme, HTI 


\section{A. Pendahuluan}

Salah satu fenomena penting yang menandai awal abad XXI ini adalah maraknya kegiatan-kegiatan yang berusaha membangkitkan spiritualitas. Secara garis besar, ada dua model spiritualitas yang berkembang di tanah air. Pertama, model spiritualitas kelembagaan. Hal ini ditunjukkan oleh berbagai jenis tarekat, yakni model spiritualitas yang memiliki pilar utama seorang murshid dengan sejumlah teknik dan tata-cara yang cukup ketat. Model ini menjadi pilihan bagi mereka yang ingin lebih mendisiplinkan diri dalam hal meningkatkan kualitas spiritual di bawah bimbingan seorang guru.

Model ini secara garis besar juga bisa dipilah menjadi dua bagian. Pertama, tarekat yang (diyakini) memiliki silsilah (geneologi spiritualitas) resmi, mulai dari murshid sampai kepada Rasulullah SAW. Tarekat-tarekat ini biasanya dikenal dengan istilah al-țariqah al-mu'tabarah (tarekat standar). ${ }^{1}$ Contoh dari tarekat jenis ini antara lain, Tarekat Qadiriyyah, Tarekat Naqsyabandiyyah, Tarekat Qadiriyyah wa Naqsyabandiyyah dan lain-lain. Yang paling popular adalah tarekat Qadiriyyah wa Naqsyabandiyyah. Kedua, tarekat yang tidak memiliki silsilah resmi yang diakui. Contoh dari tarekat ini antara lain tarekat Wahidiyyah, tarekat al-Rasuli dan lain-lain Pemilahan seperti ini sebenarnya dimaksudkan untuk memagari tarekat agar tidak keluar dari norma-norma syariah dan untuk membedakannya dari gerakan-gerakan kebatinan.

Untuk mendapatkan pengakuan dan penerimaan dari masyarakat, sebuah tarekat memang tidak selamanya mengandalkan statusnya sebagai almu'tabarah. Kenyataan menunjukkan bahwa tidak sedikit tarekat mu'tabarah yang tidak begitu dikenal di masyarakat. Sebaliknya ada juga tarekat tidak mu'tabarah yang diterima luas oleh masyarakat. Sebagai contoh, tarekat alRasuli yang dipelopori oleh Syeikh Syakir di Desa Keji Kecamatan Ungaran Kabupaten Semarang yang kini mulai mendapat perhatian luas dari masyarakat. Masyarakat berduyun-duyun datang untuk mengurangi dahaga spiritual mereka. Posisi Syeikh Syakir yang sekaligus menjadi lurah desa tersebut menjadikannya semakin diperhitungkan.

${ }^{1}$ Martin van Bruinessen, Tarekat Naqsyabandiyah di Indonesia, (Bandung: Mizan, 1996), h. 71. 
Bahkan Pemerintah Kota Semarang ingin mengembangkannya sebagai Desa Spiritual (spiritual village). ${ }^{2}$ Padahal, dan tanpa terlalu dipedulikan oleh masyarakat, kontroversi seputar keabsahan tarekat tersebut dan bahkan latar belakang geneologi spiritualitas (silsilah) Syeikh Syakir sendiri terus bermunculan. Gaung tarekat ini semakin meluas ketika MURI (Museum Rekor Indonesia) mencatat salah satu kegiatannya, yakni sujud syukur (dengan peserta) terpanjang. ${ }^{3}$ Memang sebagai sebuah lembaga spiritualitas, tarekat memiliki banyak faktor untuk dapat diterima di tengah-tengah masyarakat.

Kedua, model spiritualitas yang tidak mengambil bentuk kelembagaan. Inilah yang oleh Komaruddin Hidayat dan Ahmad Gaus AF disebut sebagai gerakan dakwah sufistik. ${ }^{4}$ Contoh dari model ini antara lain Majelis Zikir Ustadz Arifin Ilham, Majelis Zikir Ustadz Haryono dan Manajemen Qolbu Darut Tauhid. ${ }^{5}$ Yang disebut terakhir ini kini mulai memudar seiring dengan tindakan poligami yang dilakukan oleh Aa Gym. Memang perlu dilakukan kajian mendalam tentang fenomena memudarnya MQ-DT (Manajemen Qolbu Darut Tauhid) akibat tindakan poligami itu. Tetapi yang sementara bisa dikemukakan adalah bahwa loyalitas jamaah terhadap model spiritualitas non-kelembagaan ini, termasuk di dalamnya MQ memang tidak seketat loyalitas para jamaah terhadap model spiritual kelembagaan, khususnya kepada seorang murshid.

Bagi mereka yang tidak ingin terlalu terikat dengan berbagai aturan di dalam tarekat, model dakwah sufistik ala Arifin Ilham dan kawan-kawan dapat menjadi alternatif. Hal ini dibuktikan oleh banyaknya jamaah yang menghadiri setiap majlis zikir akbar yang mereka selenggarakan. Umumnya mereka adalah masyarakat perkotaan, yang biasa dikenal dengan istilah komunitas urban sufisme.

Secara umum, kedua model spiritualitas itu sama-sama mendapat sambutan luas di tengah masyarakat. Banyak faktor yang dikemukakan mengenai fenomena ini, antara lain dampak negatif modernitas yang mengakibatkan

2 Suara Merdeka, Jumat, 22 Pebruari 2007.

3 Suara Merdeka, Kamis, 1 Maret 2007.

4 Komaruddin Hidayat dan Ahmad Gaus AF (ed.), Islam, Negara dan Civil Society, Oakarta: Paramadina, 2005), h. 76.

5 Ibid. 
manusia kekeringan dimensi rohaniahnya dan membuat mereka merasa "terasing" dengan dirinya sendiri. Keterasingan ini pada gilirannya akan menimbulkan berbagai dampak negatif, dan yang paling berbahaya adalah keperpecahan kepribadian (split personality). ${ }^{6}$ Dalam perspektif psikoterapi, keadaan inilah yang turut memberikan andil besar bagi munculnya sejumlah penyakit akut.

Di sisi lain, tidak sedikit pula pihak-pihak yang dengan tegas menolak tasawuf, khususnya yang telah melembaga ke dalam bentuk tarekat. Dalam konteks kenegaraan, penolakan itu sebenarnya hanya dilakukan oleh Kerajaan Arab Saudi dan Republik Turki. Alasan palarangan keduanya pun sangat berbeda. Saudi Arabia melarang tasawuf karena dinilai bertentangan dengan ajaran-ajaran Islam murni (puritanisme ortodoks), sedang Turki melarangnya karena bertentangan dengan paham hidup modern (sekularisme). Suatu pertemuan yang mungkin cukup ironis antara kedua ekstremitas gaya hidup yang menguasai kaum Muslim di dunia. Mungkin lebih tepat dikatakan bahwa ajaran-ajaran Muhammad ibn Abdul Wahhab (di Saudi Arabia) sangat anti-sufisme dan tarekat karena adanya praktek-praktek yang mengagungkan orang-orang saleh dan makam-makam mereka, meskipun bukan merupakan ajaran asketik dan esoterik pada tasawuf. Sedangkan kaum Kemalis (Turki) lebih cenderung menilainya sebagai bentuk kekolotan saja, sebagaimana juga gejala-gejala keagamaan lain, sampai-sampai soal pemakaian huruf dan bahasa Arab. ${ }^{7}$

Di Indonesia, pola-pola penolakan terhadap tasawuf dan tarekat lebih berkiblat pada model penolakan Saudi Arabia, yakni lebih dikarenakan pada alasan kemurnian ajaran agama. Dari segi pandangan keagamaan, mereka ingin kembali kepada ajaran agama yang murni dan mendasar. Itulah sebabnya mereka sering diidentifikasi (meski tidak sepenuhnya tepat dan mereka sendiri juga menolaknya) sebagai fundamentalis. Dan dari segi gerakan, mereka menyuarakan pembentukan negara Islam dan tidak jarang menggunakan pola kekerasan, sehingga mereka juga sering diidentifikasi sebagai kaum radikal. Dalam konteks Indonesia, yang menjadi pelopor gerakan ini

\footnotetext{
6 Uraian lebih lanjut mengenai hal ini dapat dilihat pada Seyyed Hussein Nashr, Nestapa Manusia Modern, (Bandung: Pustaka, 1995).

7 Nurcholish Madjid, Bilik-bilik Pesantren: Sebuah Potret Perjalanan (Jakarta: Paramadina, 1997), h. 54.
} 
antara lain Komite Islam untuk Solodiritas Dunia Islam (KISDI), Majelis Mujahidin Indonesia (MMI), Hizbut Tahrir Indonesia (HTI), Front Pembela Islam dan Furum Komunikasi Ahlussunnah wal-Jamaah yang lebih dikenal sebagai Laskar Jihad. ${ }^{8}$

Hizbut Tahrir Indonesia yang mulai menampakkan diri di Indonesia pasca kejatuhan rezim Orde Baru memang merupakan sebuah gerakan politik. Dengan tegas mereka menyatakan diri sebagai gerakan politik, bukan lembaga agama dan bukan pula lembaga pendidikan. ${ }^{9}$ Namun dalam prakteknya mereka juga memiliki salah satu divisi dakwah yang melakukan pendalaman terhadap ajaran-ajaran Islam. Secara umum, seperti dikemukakan oleh Ustadz Ainul Yaqin yang menjadi Ketua Lajnah Tarbiyyah Hizbut Tahrir Indonesia (HTI) Jawa Tengah, dalam mengkaji Islam mereka ingin kembali kepada ajaran Islam yang murni, yakni Islam seperti yang ada di dalam alQur'an dan al-Sunnah. ${ }^{10}$ Dengan kata lain, Hizbut Tahrir ini juga menganut paham puritanisme ortodoks, paham yang (sebagaimana dikemukakan di atas) sangat menolak keras tasawuf dan tarekat.

Namun demikian, menarik untuk dicermati bahwa dalam kajian-kajian yang diselenggarakan oleh HTI Jawa Tengah ini juga banyak disinggung soalsoal yang selama ini menjadi tema-tema utama kajian tasawuf, seperti pembersihan hati, tawakkal, ikhlas, sabar dan lain-lain. Barangkali, hal ini dapat dianalogkan dengan kecaman Ibn Taimiyyah terhadap tasawuf. Di satu sisi, banyak orang yang menganggap bahwa Ibn Taimiyyah adalah orang yang anti-tasawuf, bahkan menjadikannya sebagai rujukan ketika melakukan penolakan terhadap tasawuf. Tetapi di sisi lain, ia sendiri sesungguhnya bertasawuf dan banyak pula pemikiran tasawufnya. Dalam Majmü' Fatāwā-nya, ia mengkhususkan dua jilid untuk membahas tasawuf, satu jilid khusus tentang tasawuf dan satu jilid tentang suluk. ${ }^{11}$

Para pemerhati tasawuf menjelaskan bahwa sebenarnya yang dikecam oleh Ibn Taimiyyah sesungguhnya bukan tasawuf secara keseluruhan, melainkan jenis tasawuf tertentu, semisal model tasawuf Imam al-Ghazali.

\footnotetext{
${ }^{8}$ Komaruddin Hidayat dan Ahmad Gaus AF, Islam, Negara dan Civil Society, h. 76.

${ }^{9}$ http://www.spr.gov.my/parti/

10 Wawancra dengan Ustadz Ainul Yaqin, 25 Pebruari 2007.

${ }^{11}$ Ibn Taimiyyah, Majmū' Fatāwā Ibn Taimiyyah, (Beirut: Dar al-Fikr, t.th.), Jil. IX dan X
} 
Karena itu Nurcholish Madjid menyimpulkan bahwa Dunia Islam sekarang ini terbagi menjadi dua sikap terhadap tasawuf. Yakni, ada yang lebih berorientasi kepada Imam al-Ghazali dan ada yang lebih berorientasi kepada Ibn Taimiyyah. Mungkin agak sulit dibuat garis pemisah, tetapi perbedaan tekanan orientasi itu sangat jelas terasa. Di Indonesia, Hamka misalnya adalah seorang pengikut Ibn Taimiyyah, sedang para kiai di pesantren sebagian besar adalah para pengikut al-Ghazali. ${ }^{12}$

Dengan demikian, mereka yang menolak tasawuf, termasuk HTI Jawa Tengah sebenarnya bukannya tidak bertasawuf. Yang mereka tolak sebenarnya jenis tasawuf tertentu. Atau setidaknya, yang mereka tolak adalah tasawuf sebagai sebuah disiplin ilmu. Tetapi hakikatnya mereka tidak akan pernah terhindar dari nilai-nilai tasawuf itu. Di samping itu, sebagai manusia mereka tidak akan pernah terlepas dari tuntutan rohaniahnya. Disadari atau tidak, mereka tetap memiliki menakisme untuk memenuhi kebutuhan rohaniahnya. Apalagi dewasa ini telah banyak ditemukan, bahwa spiritualitas adalah sesuatu yang built-in dalam diri manusia. Karena di dalam dirinya terdapat perangkatnya, yang biasa disebut sebagai God Spot. ${ }^{13}$ Tetapi karena secara verbal mereka menolak term tasawuf, maka di sini digunakan istilah spiritualitas. Penelitian ini hendak mengkaji lebih jauh bagaimana HTI Jawa Tengah mengekpresikan spiritualitas mereka dalam bingkai keberagamaan mereka baik secara teoretis maupun praktis.

\section{B. Genealogi Spiritualitas}

Term spiritual, berasal dari bahasa Latin, dari akar kata spiritus, yang berarti nafas atau hidup. Spiritualitas menjadi titik perhatian para peneliti di bidang psikologi agama dan kebudayaan secara luas baru beberapa dekade terakhir ini. Spiritualitas merupakan konsep yang memiliki kedekatan dengan agama.

Mulanya kata ini menunjuk hanya dalam konteks agama. Kata tersebut sering disebut di dalam Kitab Perjanjian Lama maupun Perjanjian Baru. Akan tetapi, setelah berkembangnya faham sekularisme dekade tahun 60-an, serta berkembangnya faham ketidakpercayaan terhadap lembaga-lembaga ke-

${ }^{12}$ Nurcholish Madjid, Bilik-bilik Pesantren...., h. 53.

${ }^{13}$ Ary Ginandjar Agustian, ESQ, (Jakarta: Penerbit Arga, 2001), h. xxii. 
agamaan, maka masyarakat Barat khususnya mengembangkan konsep spiritualitas yang terpisah dari makna dan konotasi agama.

Karakteristik utama pengalaman spiritual adalah: (1) a distinct event and a cognitive appraisal of that event resulting in a personal conviction of God's Existence, (sebuah peristiwa yang jelas dan sebuah pencapaian kesadaran yang mengakibatkan keyakinan pribadi tentang eksistensi Tuhan), dan (2) the perception of a highly internalized relationship between God and the person (i.e. God dwells within and a corresponding feeling of unity or closeness to God) (persepsi tentang hubungan yang sangat dalam antara Tuhan dan individu, yakni Tuhan "tinggal" di dalam dan sebuah perasaan yang mendalam tentang kesatuan atau kedekatan dengan Tuhan). ${ }^{14}$

Dalam bahasa Arab, spirit sama dengan rūh, dan spiritualitas sama dengan rūhiyyah atau rūḥaniyyah. Dan dalam Islam, dimensi ruhiyyah atau ruhaniyyah ini merupakan salah satu misteri. Maksudnya, merupakan sebuah aspek, yang hanya dapat ditangkap dengan mata batin (al-bașirah), tetapi sulit untuk diungkap dengan bahasa verbal. Itulah sebabnya, spiritualitas dalam Islam mengalami sejumlah problem kebahasaan. Bahkan dalam sejarahnya pernah terjadi konflik yang sangat tajam antara kaum strukturalis, yang diwakili oleh kaum fuqaha dan kaum spiritualis yang diwakili oleh kaum sufi. Bahkan konflik itu tetap berlangsung sampai sekarang.

Dalam Islam, spiritualitas secara konseptual dibahas secara luas dalam disiplin ilmu tasawuf. Sebenarnya tasawuf ini adalah pengembangan lebih jauh dari salah satu pilar agama, yakni ihsan. Di samping ihsan, ada dua pilar lain yang sama-sama dikembangkan menjadi disiplin ilmu keislaman. Pertama, pilar Islam, yang kemudian dikembangkan menjadi disiplin ilmu fiqih. Kedua, pilar iman yang kemudian dikembangkan menjadi disiplin ilmu kalam. Inilah yang kemudian dikenal sebagai trilogi Islam. ${ }^{15}$

Dibanding dua pilar lainnya, tasawuf cenderung dipandang secara kurang proporsional. Ia sering dituduh tidak Islami, karena adanya sejumlah kecenderungan menyimpang. Padahal, kedua pilar lainnya pun tidak terlepas dari sejumlah penyimpangan oleh oknum-oknum tertentu, terutama bidang

\footnotetext{
14 Peter C. Hill and Ralph W. Hood, Measures of Religiousity, (Birmingham, Alabama: Religious Education Press, 1999), p. 359-360.

15 Sachiko Mujrata dan William C. Chittick, Trilogi Islam: Islam, Iman dan Ihsan, Uakarta: Raja Grafindo Persada, 1997).
} 
ilmu kalam yang justru memiliki banyak sekali varian (sekte) yang "dianggap" menyimpang. Penolakan paling lantang terhadap tasawuf disuarakan oleh mereka yang menganut paham puritenisme ortodoks, sebagaimana telah disinggung di muka. Alasan utamanya, tasawuf tidak memiliki referensi di dalam al-Qur'an dan al-Sunnah serta generasi salaf Islam.

Hizbut Tahrir adalah sebuah partai politik yang berideologi Islam. Politik merupakan kegiatannya dan Islam adalah ideologinya. Hizbut Tahrir bergerak di tengah-tengah umat dan bersama-sama mereka berjuang untuk menjadikan Islam sebagai permasalahan utamanya serta membimbing mereka untuk mendirikan kembali sistem kekhilafahan dan menegakkan hukum yang diturunkan Allah dalam realitas kehidupan.

Hizbut Tahrir merupakan organisasi politik, bukan organisasi kerohanian (seperti tarekat), bukan badan ilmiah (seperti lembaga agama atau badan penelitian), bukan institusi pendidikan (akademik), dan bukan pula lembaga sosial (yang bergerak di bidang sosial dan kemasyarakatan). Ideaidea Islam menjadi jiwa, inti dan sekaligus rahasia kelangsungan kelompoknya. ${ }^{16}$

Namun demikian, karena menurut mereka Islam harus menjadi pandangan hidup dan meliputi seluruh aspek kehidupan, maka mereka pun menggunakan model dakwah tertentu untuk memuluskan tujuan mereka itu. Dalam dakwah-dakwah mereka itulah, pandangan keagamaan mereka dapat dipotret. Termasuk dalam hal bagaimana mengekpresikan spiritualitas, mereka juga memiliki pandangan yang khas. Sebagai salah satu elemen penganut paham puritanisme ortodoks, mereka pun secara resmi menolak tasawuf sebagai wahana mengekspresikan spiritualitas dalam Islam.

\section{Tentang Hizbut Tahrir Indonesia (HTI) Jawa Tengah}

\section{Sejarah Singkat HTI Jawa Tengah}

\section{a. Pengertian}

Hizbut Tahrir adalah sebuah partai politik yang berideologi Islam. Politik merupakan kegiatannya, dan Islam adalah ideologinya. Hizbut Tahrir ber-

${ }^{16} \mathrm{http}: / /$ www.spr.gov.my/parti/ 
gerak di tengah-tengah umat, dan bersama-sama mereka berjuang untuk menjadikan Islam sebagai permasalahan utamanya, serta membimbing mereka untuk mendirikan kembali sistem khiläfah dan menegakkan hukum yang diturunkan Allah SWT dalam realitas kehidupan. Hizbut Tahrir merupakan organisasi politik, bukan organisasi kerohanian (seperti tarekat), bukan lembaga ilmiah (seperti lembaga studi agama atau badan penelitian), bukan lembaga pendidikan (akademis), dan bukan pula lembaga sosial (yang bergerak di bidang sosial kemasyarakatan). Ide-ide Islam menjadi jiwa, inti, dan sekaligus rahasia kelangsungan kelompoknya.

Hizbut Tahrir berdiri pada tahun 1953 di al-Quds (Baitul Maqdis), Palestina. Gerakan yang menitikberatkan perjuangan membangkitkan umat di seluruh dunia untuk mengembalikan kehidupan Islam melalui tegaknya kembali khilāfah Islāmiyyah ini dipelopori oleh Syeikh Taqiyuddin al-Nabhani, seorang ulama alumni al-Azhar Mesir, dan pernah menjadi hakim di Mahkamah Syariah di Palestina. ${ }^{17}$

\section{b. Latar Belakang dan Tujuan Pendirian}

Hizbut Tahrir didirikan dalam rangka memenuhi seruan Allah SWT:

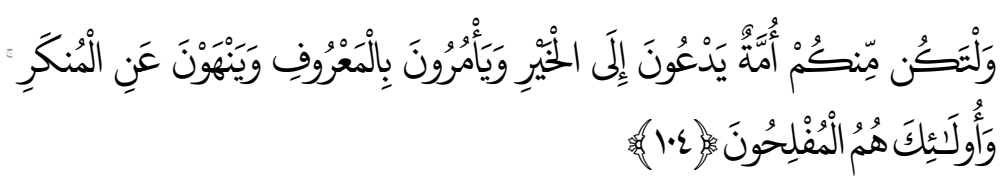

“(Dan) hendaklah ada di antara kalian segolongan umat (jamaah) yang menyeru kepada kebaikan (mengajak memilih kebaikan, yaitu memeluk Islam), memerintahkan kepada yang ma'ruf dan melarang dari yang munkar. Merekalah orang-orang yang beruntung." 18

Hizbut Tahrir bermaksud membangkitkan kembali umat Islam dari kemerosotan yang amat parah, membebaskan umat dari ide-ide, sistem perundang-undangan, dan hukum-hukum kufur, serta membebaskan mereka dari cengkeraman dominasi dan pengaruh negara-negara kafir. Hizbut Tahrir bermaksud juga membangun kembali Dawlah Khiläfah Islāmiyyah di muka

${ }^{17} \mathrm{http} / /$ /hizbut-tahrir.or.id/tentang-kami/

${ }^{18}$ QS. Ali Imran [3]: 104. 
bumi, sehingga hukum yang diturunkan Allah SWT dapat diberlakukan kembali.

Hizbut Tahrir bertujuan melanjutkan kehidupan Islam dan mengemban dakwah Islam ke seluruh penjuru dunia. Tujuan ini berarti mengajak kaum Muslimin kembali hidup secara Islami dalam Darul Islam dan masyarakat Islam. Di mana seluruh kegiatan kehidupannya diatur sesuai dengan hukumhukum syara'. Pandangan hidup yang akan menjadi pedoman adalah halal dan haram, di bawah naungan Dawlah Islämiyyah, yaitu dawlah khiläfah, yang dipimpin oleh seorang khalifah yang diangkat dan dibai'at oleh kaum Muslimin untuk didengar dan ditaati agar menjalankan pemerintahan berdasarkan Kitabullah dan Sunnah Rasul-Nya, serta mengemban risalah Islam ke seluruh penjuru dunia dengan dakwah dan jihad.

Di samping itu Hizbut Tahrir bertujuan membangkitkan kembali umat Islam dengan kebangkitan yang benar, melalui pola pikir yang cemerlang. Hizbut Tahrir berusaha untuk mengembalikan posisi umat ke masa kejayaan dan keemasannya seperti dulu, di mana umat akan mengambil alih kendali negara-negara dan bangsa-bangsa di dunia ini. Dan negara khiläfah akan kembali menjadi negara nomor satu di dunia—sebagaimana yang terjadi pada masa silam-yakni memimpin dunia sesuai dengan hukum-hukum Islam. Hizbut Tahrir bertujuan pula untuk menyampaikan hidayah (petunjuk syariat) bagi umat manusia, memimpin umat Islam untuk menentang kekufuran beserta segala ide dan peraturan kufur, sehingga Islam dapat menyelimuti bumi.

\section{c. HTI Jawa Tengah}

Hizbut Tahrir masuk ke Indonesia pada tahun 1980-an dengan merintis dakwah di kampus-kampus besar di seluruh Indonesia, sehingga disebut Hizbut Tahrir Indonesia (HTI). Pada era 1990-an ide-ide dakwah Hizbut Tahrir Indonesia merambah ke masyarakat, melalui berbagai aktivitas dakwah di masjid, perkantoran, perusahaan, dan perumahan.

Di tingkat pusat, kepengurusan HTI disebut DPP (Dewan Pimpinan Pusat), di tingkat propinsi disebut DPD (Dewan Pimpinan Daerah) I dan di tingkat kabupaten/kota disebut DPD II. Sampai saat ini, belum ada kepengurusan di tingkat kecamatan. 
Di Jawa Tengah, HTI sebenarnya sudah mulai masuk sejak tahun 1990, melalui sebuah usaha rintisan yang dilakukan oleh sejumlah mahasiswa UNDIP Semarang, dipelopori oleh Abdullah, asal Cirebon, yang waktu itu masih berada di semester empat Fakultas Teknik. Melalui kegiatan yang dirintisnya bersama teman-temannya, HTI bergerak dari kampus ke kampus. Namun baru pada tahun 2000, yakni setelah ada konggres umat Islam pertama di Stadion Gelora Bung Karno Jakarta, HTI Jawa Tengah mulai memiliki kepengurusan.

Saat ini, DPD I HTI Jawa Tengah bersekretariat di Jalan Abdurrahman Saleh No. 17, yang lebih dikenal dengan sebutan markas Absa. Yang ditempati adalah rumah milik dokter Amanullah, seorang dokter ahli saraf terkemuka di Semarang. Hal ini bermula dari keberadaan anaknya, yang menjadi salah seorang simpatisan Hizbut Tahrir sewaktu masih kuliah di Amerika. Dia memang mengenal Hizbut Tahrir ketika masih berada di Amerika. Dan sewaktu sudah pulang ke Indonesia, ia memberikan ijin agar salah satu rumah milik ayahnya yang kebetulan memang masih kosong, dijadikan sebagai sekretariat HTI Jawa Tengah. ${ }^{19}$

Menurut salah seorang aktivis HTI Jawa Tengah, keberadaan sekretariat bagi HTI sebenarnya tidak terlalu penting, karena sekretariat sesungguhnya ada di rumah masing-masing pengurus. Artinya, ketika tidak ada sekretariat khusus pun, HTI tetap akan menjalankan aktivitasnya di rumah-rumah para pengurusnya. ${ }^{20}$ Barangkali inilah alasannya, mengapa secara fisik tampilan sekretariat HTI Jawa Tengah sangat jauh dari ideal untuk dikatakan sebagai sebuah sekretariat organisasi di tingkat propinsi. Penataannya sangat sederhana, untuk tidak mengatakan agak awut-awutan, dan lebih mirip seperti tempat kos mahasiswa. Beberapa dos tempat pakaian berserakan, sebuah rak buku yang berisi buku-buku, CD dan VCD pegangan pokok bagi HTI dan untuk dijual, sebuah televisi dan sebuah komputer (internet).

Dari segi kepengurusan, DPD I HTI Jawa Tengah terdiri dari ketua, yang dibantu oleh humas, sekretaris dan bendahara, dan dibantu oleh sejumlah lajnah. Ketuanya adalah Ustadz Ir. Abdullah, yang sekaligus menjabat sebagai

\footnotetext{
19 Wawancara dengan Ir. Abdullah, ketua HTI Jateng, di rumahnya Perum Gedawang Permai I, Blok D Nomor 8, pada tanggal 22 September 2008, pukul 21.00 WIB.

${ }^{20}$ Wawancara dengan Yusuf, salah seorang aktivis yang lebih banyak tinggal di markas Absa, pada tanggal 9 September 2008, di markas Absa, pukul 11.00 WIB.
} 
humas. Sekretarisnya adalah Rohmadi, dan bendaharanya adalah Ahmadi, MM. Sampai saat ini, ada enam lajnah, yaitu: (1) Lajnah Tsaqafiyyah, yakni lembaga yang membidangi kajian hukum Islam, dijabat oleh Ustadz Fadloli (Solo), alumnus Fakultas Pertanian UNS; (2) Lajnah Siyasiyah, yakni lembaga yang membidangi masalah politik; (3) Lajnah Mashlahiyyah, yakni lembaga yang membidangi masalah kebijakan publik. Kedua lajnah ini dijabat oleh Ustadz Singgih Saptadi, ST, MT, alumnus teknik industri Undip; (4) Lajnah I'laniyyah, yakni lembaga yang menangani publikasi atau media massa, dijabat oleh Arif Tri Handoyo, S.Sos (Semarang); (5) Lajnah Fa'aliyyah, yakni lembaga yang menangani masalah hubungan dengan para tokoh, dijabat oleh Ustadz Ainul Yaqin. Tugas ini lebih efektif, karena dia juga menjadi salah seorang aktivis dari sebuah lembaga penterjemahan al-Qur'an, yakni sebuah lembaga yang memberikan bantuan untuk memahami secara lebih sederhana terjemah al-Qur'an; (6) Lajnah Thullab wal-Jami'ah, yakni lembaga yang menangani masalah mahasiswa dan perguruan tinggi, dijabat oleh Hendar, ST (Undip). ${ }^{21}$

Sampai saat ini, hampir di semua kabupaten/kota di Jawa Tengah sudah ada DPD II HTI, baik yang berdiri sendiri per kabupaten atau yang merupakan gabungan dari sejumlah kabupaten kota. Yang gabungan, misalnya Brebes dan Tegal membentuk sebuah DPD II HTI, lalu Pekalongan, Pemalang dan Batang membentuk sebuah DPD II HTI. Hanya tiga kabupaten yang belum memiliki DPD II, yaitu Demak, Wonosobo dan Purwodadi.

\section{Model Dakwah HTI Jawa Tengah}

Hizbut Tahrir dalam menyampaikan dakwahnya berusaha membangkitkan dan menggerakkan pemikiran. Hizbut Tahrir berpendapat bahwa dakwah Islam harus dibangun atas dasar pembentukan pemikiran dan wajib dikembangkan sebagai qiyādah fikriyyah, yaitu kepemimpinan umat berdasarkan pemikiran. Sebab pemikiran yang jernih dan cemerlanglah yang amat dibutuhkan dalam hidup ini. Dan manusia akan bangkit di atas landasan tersebut, yaitu berupa suatu pemikiran yang mampu memperlihatkan hakikat segala sesuatu sehingga dapat dipahami dengan benar.22

\footnotetext{
${ }^{21}$ Wawancara dengan Ir. Abdullah, ibid.

22 Taqiyuddin al-Nabhani, Pokok-pokok Pikiran Hizbut Tahrir, terjemahan dari Mafahim Hizbut Tahrir oleh Abu Afif, (Jakarta: Pustaka Thariqul Izzah, 1993), h. 11.
} 
Metode yang ditempuh Hizbut Tahrir dalam mengemban dakwah adalah hukum-hukum syara', yang diambil dari țarīqah (metode) dakwah Rasulullah SAW, sebab țariqah itu wajib diikuti. Sebagaimana firman Allah SWT:

"Sesungguhnya telah ada pada (diri) Rasulullah itu suri teladan yang baik bagi kalian, (yaitu) bagi orang yang mengharap (rahmat) Allah dan kedatangan Hari Kiamat, dan dia banyak menyebut Allah (dengan membaca dzikir dan mengingat Allah)." 23

"Katakanlah: 'Jika kalian (benar-benar) mencintai Allah, ikutilah aku, niscaya Allah mengasihi dan mengampuni dosa-dosa kalian." 24

"Apa saja yang dibawa Rasul untuk kalian, maka ambilah. Dan apa saja yang dilarangnya bagi kalian, maka tinggalkanlah." 25

Dan banyak lagi ayat lain yang menunjukkan wajibnya mengikuti perjalanan dakwah Rasulullah SAW, menjadikan beliau suri teladan, dan mengambil ketentuan hukum dari beliau.

Berhubung kaum Muslimin saat ini hidup di Dar al-Kufur-karena diterapkan atas mereka hukum-hukum kufur yang tidak diturunkan Allah SWT-maka keadaan negeri mereka serupa dengan Makkah ketika Rasulullah SAW diutus (menyampaikan risalah Islam). Untuk itu fase Makkah wajib dijadikan sebagai tempat berpijak dalam mengemban dakwah dan meneladani Rasulullah SAW.

Dengan mendalami sirah Rasulullah SAW di Makkah hingga beliau berhasil mendirikan Dawlah Islämiyyah di Madinah, akan tampak jelas beliau menjalani dakwahnya dengan beberapa tahapan yang sangat jelas ciri-cirinya. Beliau melakukan kegiatan-kegiatan tertentu yang tampak dengan nyata tujuan-tujuannya. Dari sirah Rasulullah SAW inilah Hizbut Tahrir mengambil metode dakwah dan tahapan-tahapannya, beserta kegiatan-kegiatan yang harus dilakukannya pada seluruh tahapan ini, karena Hizbut Tahrir mensuriteladani kegiatan-kegiatan yang dilakukan Rasululah SAW dalam seluruh tahapan perjalanan dakwahnya.

${ }^{23}$ QS. al-Ahzab [33]: 21.

${ }^{24}$ QS. Ali Imran [3]: 31.

${ }^{25}$ QS. al-Hasyr [59]: 7. 
Berdasarkan sirah Rasulullah SAW tersebut, Hizbut Tahrir menetapkan metode perjalanan dakwahnya dalam 3 (tiga) tahapan berikut: 26

Pertama, Tahapan Pembinaan dan Pengkaderan (Marhalah al-Tațif), yang dilaksanakan untuk membentuk kader-kader yang mempercayai pemikiran dan metode Hizbut Tahrir, dalam rangka pembentukan kerangka tubuh partai.

Kedua, Tahapan Berinteraksi dengan Umat (Marhalah Tafa'ul ma'a alUmmah), yang dilaksanakan agar umat turut memikul kewajiban dakwah Islam, hingga umat menjadikan Islam sebagai permasalahan utamanya, agar umat berjuang untuk mewujudkannya dalam realitas kehidupan.

Ketiga, Tahapan Penerimaan Kekuasaan (Marhalah Istilzam al-Hukm), yang dilaksanakan untuk menerapkan Islam secara menyeluruh dan mengemban risalah Islam ke seluruh dunia.

Tentang jihad, Hizbut Tahrir agaknya lebih menghindari jihad fisik, kecuali dalam kerangka mempertahankan diri. Itulah sebabnya, Hizbut Tahrir tidak memiliki lascar, seperti gerakan-gerakan Islam yang lain. Bagi mereka, senjata mereka adalah pemikiran, sehingga tidak memerlukan laskar. Di sinilah letak kelebihan HTI dibanding gerakan-gerakan Islam yang lebih sering mengedepankan kekuatan fisik, meski sebenarnya tidak benar-benar kuat, seperti FPI, MMI dan lain-lain. Karena itu, Anick HT dari JIL dalam Diskusi Publik bertajuk: "Menyoroti Fenomena Kemunculan Sekte-sekte Keagamaan di Indonesia" pada hari Rabu, 28 November 2007 berseloroh: "Bagusnya, HTI tidak menggunakan kekerasan."27

Karena itu, dalam polemiknya dengan kelompok-kelompok lain, HTI masih tetap berpegang teguh kepada prinsip mengedepankan pemikiran. Dalam hal ini, ada dua kelompok yang berseberangan dengan HTI. Pertama, JIL (Jaringan Islam Liberal). Dasarnya adalah karena menurut mereka, JIL terlalu liberal, sehingga secara 'aqliyyah, apalagi nafsiyyah sudah keluar dari kaidah yang ditentukan oleh Hizbut Tahrir. Meski keduanya sesungguhnya sama-sama "liberal," hanya beda bahasa dan pemaknaan saja. Kedua, kelompok Salafi. Polemic antara keduanya muncul karena bagi Salafi, HTI memiliki unsur pengembangan pemikiran, sehingga mereka sebut sebagai Neo249-250.

${ }^{26}$ Hafidz Abdurrahman, Diskursus Islam, Politik dan Spiritual, (Bogor: al-Azhar Press, 2004), h.

27 http://islamlib.com/id/artikel/agama-agama-besar-dilanda-krisis/ 
Mu'tazilah. Di saming itu, HTI menurut Salafi tidak berani berdakwah secara tegas. ${ }^{28}$

\section{Pandangan HTI Jawa Tengah tentang Tasawuf dan Tarekat}

Dalam studi Islam, tasawuf merupakan salah satu bidang kajian yang secara spesifik mengkaji secara detail salah satu dimensi agama Islam, yakni dimensi Ihsan. Namun karena istilah yang digunakan bukan ihsan, melainkan tasawuf, maka kontroversi seputar keabsahannya pun tidak bisa dihindari. Ada yang menerima secara mutlak, ada yang menolak secara mutlak dan ada yang menerima atau menolak dengan sejumlah catatan. HTI Jawa Tengah bisa dikategorikan ke dalam kelompok yang terakhir.

Salah satu aspek yang ditolak oleh HTI adalah wacana tasawuf tentang ruh. Menurut HTI, apa yang dikatakan sebagian orang, bahwa manusia itu terbentuk dari campuran materi dan ruh-sehingga apabila materi yang ada padanya mampu mendominasi ruh jadilah ia orang jahat dan jika ruh yang mendominasi dalam dirinya jadilah ia orang baik dan bahwasanya manusia harus memenangkan ruh atas materi agar menjadi orang baik-adalah salah.

Mengenai arti ruh, orang-orang yang beriman dengan adanya Tuhan berulangkali menggunakan lafazh rūh, kerohanian dan aspek rohani. Sebenarnya yang mereka maksud adalah adanya pengaruh dari Sang Pencipta di suatu ruang atau tempat; atau apa yang dapat disaksikan dari tanda-tanda yang berkaitan dengan hal-hal ghaib; atau keberadaan sesuatu yang dapat diketahui, yang tidak mungkin muncul kecuali dari Allah; atau yang semakna dengan hal ini. Semua makna yang mereka sebut sebagai ruh, kerohanian dan aspek rohani serta yang sejenisnya ini merupakan makna-makna yang umum, kabur dan belum jelas. Ketidakjelasan ini menimbulkan sejumlah kekacauan, antara lain: ${ }^{29}$

Pertama, sebagian mencampuradukkannya dengan ruh yang berarti nyawa atau rahasia hidup. Kemudian mereka katakan bahwa manusia terbentuk dari campuran materi dan ruh (sebagaimana ajaran spiritualisme). Karena merasakan adanya ruh sebagai nyawa atau rahasia kehidupan dalam dirinya dan adanya ruh dalam arti kerohanian dan aspek rohani, mereka lalu

\footnotetext{
28 Wawancara dengan Ustadz Abdullah, ibid.

${ }^{29}$ Ibid., h. 15.
} 
mengira bahwa ruh dengan pengertian kerohanian sama dengan pengertian ruh yang berarti nyawa atau muncul dari nyawa. Mereka lupa bahwa pada hewan pun terdapat ruh yang berarti nyawa. Kendati demikian, hewan tidak mempunyai kerohanian atau aspek rohani.

Kedua, penggunaan istilah kerohanian untuk seseorang yang merasakan kepuasan jiwa, sehingga ada yang mengatakan tentang dirinya: "Aku telah merasakan suatu kerohanian yang tinggi," atau "Si Fulan mempunyai suatu kerohanian yang agung."

Ketiga, tatkala seseorang mendatangi suatu tempat, kemudian ia merasakan kepuasan atau kenikmatan, maka tempat itu dikatakan sebagai mengandung aspek rohani atau kerohanian.

Keempat, ada sementara orang yang pada akhirnya melaparkan diri, menyengsarakan jasadnya dan menelantarkan tubuhnya dengan maksud untuk memperkuat ruhnya.

Penolakan ini kemudian berimplikasi kepada penolakan terhadap konsep-konsep tasawuf yang lain, seperti 'uzlah dan khalwah. ${ }^{30}$ Bagi HTI, manusia yang baik bukan manusia yang mengucilkan diri, melainkan manusia yang terlibat aktif dalam menata kehidupan masyarakat, yakni terlibat dalam aktivitas dakwah.

Di samping itu, ada sejumlah pemikiran yang menurut mereka bersumber atau mendapat pengaruh dari ajaran Hindu dan Budha, seperti asketisme serta filsafat. Padahal Hizbut Tahrir telah memilih pandanganpandangan, pemikiran-pemikiran dan hukum-hukum Islami dan hanya berasal dari Islam. Tidak ada di dalamnya hal-hal yang tidak Islami, bahkan tidak terpengaruh sedikit pun oleh sesuatu yang berasal dari luar Islam, sematamata Islam dan hanya berdasar pada dasar-dasar Islam serta nash-nashya secara murni. ${ }^{31}$

Tentang tarekat, yang menjadi titik tekan penolakan adalah modelmodel riyādah yang terpengaruh oleh kehidupan asketisme dalam agama Hindu dan Budha. Karna model-model ini berimplikasi, menurut mereka, pada lemahnya semangat juang umat. Dengan kata lain, tarekat ini memiliki andil terhadap terjadinya kemunduran umat Islam.

${ }^{30}$ Wawancara dengan Ustadz Abdullah, ibid.

${ }^{31}$ Taqiyuddin al-Nabhani, Pokok-pokok Pikiran Hizbut Tahrir, h. 11. 
Tetapi yang patut dicatat, penolakan HTI tidak bersifat umum. Artinya, ada model-model tasawuf atau tarekat tertentu yang tidak ditolak, sepanjang tidak mengandung unsur-unsur yang menjadi alasan penolakan mereka itu. Itulah sebabnya, Lajnah Fa'aliyyah berusaha untuk menjalin hubungan dengan sejumlah tokoh tarekat. Bagi mereka, kaum tarekat kurang memiliki pemahaman yang cukup tentang realitas masyarakat, sehingga solusi yang ditawarkan kaum tarekat pun kurang sesuai. Maka dengan pendekatan itu, HTI bermaksud memberikan informasi yang menurut mereka benar tentang realitas masyarakat.

\section{Spiritualitas HTI Jawa Tengah}

\section{a. Model Spiritualitas HTI Jawa Tengah}

Dengan berdasar pada pokok-pokok pikiran yang telah digagas oleh alNabhani, maka model spiritualitas HTI bisa dikemukakan ke dalam sejumlah butir berikut:

Pertama, spiritualitas bagi HTI adalah kesadaran berhubungan dengan Allah SWT (idrak șilah billāh). Kesadaran manusia akan hubungan-Nya dengan Allah inilah yang mereka sebut dengan ruh. Kesadaran ini tidak hanya dibangun sewaktu melaksanakan ibadah mahḍh, tetapi harus menjadi landasan bagi seluruh perikehidupan manusia. Ekspresi dari kesadaran ini adalah dorongan untuk hidup dalam naungan hukum-hukum Allah. Itulah sebabnya, HTI berusaha keras untuk menerapkan syariah Islam. Karena hanya dalam kerangka syariat Islam itulah, spiritualitas itu dapat diwujudkan.

Dengan pemahaman spiritualitas yang seperti ini, maka bisa dipahami bahwa pola-pola yang digunakan untuk menguatkan kualitas spiritual adalah dengan melaksanakan syariat, dimulai dari ibadah-ibadah wajib dan ditambah dengan ibadah-ibadah sunnah, misalnya qiyāmu al-lail, tadarus alQur'an dan zikir. Dalam hal ini, mereka juga mengakomodasi rangkaian zikir yang selama ini dikenal dengan istilah tahlïl, yang ditolak oleh sejumlah gerakan Islam. Alasannya adalah, kalau al-ma'thūrät itu diterima, maka tahlil pun harus diterima, karena keduanya sama-sama merupakan formulasi ulama.

Namun demikian, pengembangan kualitas spiritual ini tidak harus menggunakan pola-pola yang baku seperti yang ada di dalam tarekat. Itulah 
sebabnya mereka tidak mengenal pelembagaan spiritualitas, apalagi mereka memang menegaskan bahwa mereka bukan lembaga kerohanian.

Kedua, HTI tidak mengenal, untuk tidak mengatakan tidak mengakui, pengalaman-pengalam spiritual seperti yang dituturkan oleh para sufi. Karena bagi mereka, pengalaman spiritual akan diukur dengan kesungguhan seseorang untuk semakin mendekatkan diri dengan syariat Islam. Dengan kata lain, pengalaman spiritual seseorang harus diukur berdasarkan dua indikator. Pertama, 'aqliyyah (pola pikir), yakni cara yang digunakan untuk memikirkan sesuatu. Kedua, nafsiyyah (pola sikap), yakni cara yang digunakan seseorang untuk memenuhi tuntutan gharizzah (naluri) dan hajat 'adawiyyah (jasmani)-nya. Kedua unsur inilah yang akan membentuk syakhshiyyah seseorang. Shakhsiyyah tidak akan disebut islāmiyyah kecuali apabila 'aqliyyah orang tersebut adalah 'aqliyyah islāmiyyah dan nafsiyyah-nya pun nafsiyyah islāmiyyah. 'Aqliyyah islāmiyyah adalah ketika seseorang memikirkan sesuatu untuk mengeluarkan keputusan hukum terhadapnya dengan menyandar kepada akidah Islam. Sedang nafsiyyah islāmiyyah adalah jika pemenuhan naluri dan kebutuhan jasmani tersebut dilaksanakan dengan sempurna berdasarkan akidah Islam. ${ }^{32}$

Ketiga, untuk membangkitkan kesadaran berhubungan dengan Allah SWT. (idrak șilah billāh) itu, ada beberapa cara yang ditempuh: (1) Melakukan pembentengan pemikiran melalui kajian rutin yang disebut dengan halaqah. Melalui halaqah ini, 'aqliyyah para anggota tetap bisa diarahkan kepada 'aqliyyah islāmiyyah. Halaqah ini harus diadakan minimal satu minggu sekali. Masing-masing tingkatan pengurus harus memiliki dan membina halaqah tersendiri. (2) Menciptakan lingkungan melalui pertemuan bulanan yang bersifat massal (pertemuan besar). Melalui pertemuan besar ini diharapkan apa yang telah dibina di dalam halaqah-halaqah itu akan tertanam lebih kuat karena adanya komunitas yang mendukung. Tetapi kemunitas seperti ini masih memiliki banyak kelemahan, karena pada akhirnya setiap shabāb (anggota laki-laki) atau shabābah (anggota perempuan) akan kembali lagi ke tengah-tengah masyarakat. Dan di masyarakatnya itulah mereka akan mendapatkan pengaruh yang lebih kuat. (3) Melakukan perubahan masyarakat. Hal ini dilakukan sebenarnya tidak lain untuk menjaga setiap individu agar

32 Hizbut Tahrir, Pilar-pilar Pengokoh Nafsiyyah Islamiyyah, terjemahan dari Min Muqawwimat Nafsiyyah Islāmiyyah oleh Yasin, (Jakarta: Tim HTI-Press, 2008), h. 9-12. 
tetap berada dalam syariat Islam. Sebab sekuat apapun shakhșiyyah yang telah terbentuk di dalam halaqah dan pertemuan besar, pada akhirnya akan terpengaruh juga oleh masyarakat dimana individu tinggal. Dan masyarakat yang berdasarkan syariah itu tidak akan terbentuk apabila tidak ada kepemimpinan yang Islami. Inilah yang menjadi landasan utama kebutuhan terhadap khiläfah. ${ }^{33}$

\section{b. Relevansi Model Spiritualitas HTI Jawa Tengah di Era Modern}

Setidaknya ada tiga hal yang bias dijadikan sebagai indikator relevansi model spiritualitas Hizbut Tahrir, yaitu:

Pertama, dari segi kesederhanaan konsep. Konsep tentang spiritualitas yang ditawarkan oleh Hizbut Tahrir relatif sederhana. Berbeda dengan spiritualitas dalam tasawuf, apalagi tasawuf falsafi. Maka simpatisan Hizbut Tahrir banyak yang berasal dari kalangan dengan latar belakang pendidikan umum dan eksak. Sebab mereka tidak memiliki perangkat yang memadai untuk memahami Islam secara lebih sophisticated. Di tengah hiruk-pikuk modernitas, maka kesederhaan konsep keagamaan, termasuk spiritualitas Hizbut Tahrir ini menemukan relevansinya.

Kedua, kemudahan mengamalkan. Relevansi selanjutnya adalah kemudahan mengamalkannya. Ada semacam logika sederhana yang mendominasi umat, yaitu bahwa tidak ada artinya banyak ilmu kalau tidak diamalkan. Meski semboyan ini benar adanya, tetapi sering dipahami tidak secara proporsional. Riyadhah-riyadhah yang dikembangkan di dalam Hizbut Tahrir relative lebih mudah dilaksanakan. Dimulai dengan ritual-ritual wajib, dilanjutkan dengan ritual-ritual sunnah, dan semuanya harus didasarkan kepada tuntutan Nabi SAW. Berbeda dengan amalan di dalam tarekat, apalagi apabila yang dimaksud adalah amalan suluk.

Ketiga, semangat aktifivisme. Semangat aktivisme yang dikembangkan oleh Hizbut Tahrir tampaknya paling sesuai dengan kebutuhan masyarakat modern. Tuntutan ekonomi yang tinggi dan persaingan yang semakin ketat mengharuskan setiap individu mengerahkan segenap kemampuannya untuk menjarah setiap detik bagi aktivitas yang bermanfaat.

33 Wawancara dengan Ustadz Abdullah, ibid. 


\section{Kesimpulan}

Berdasarkan temuan-temuan di atas, beberapa kesimpulan dapat dikemukakan di sini. Pertama, HTI Jawa Tengah memiliki pandangan yang relatif moderat terhadap tasawuf dan tarekat. HTI hanya menolak unsurunsur yang menurut mereka berasal dari luar Islam, seperti karena pengaruh dari ajaran Hindu dan Budha serta filsafat. Juga unsur-unsur yang berdampak pada melemahnya semangat juang, sehingga mengakibatkan kemunduran umat Islam. Dari sini, model spiritualitas HTI lebih mirip dengan apa yang dikembangkan oleh Neo-Sufisme. Meski demikian, spiritualitas HTI tetap tidak bisa disebut sebagai Neo-Sufisme, karena mereka memang tidak mengembangkan pemikiran secara khusus di bidang sufisme. Kedua, ekspresi spiritualitas HTI tercermin di dalam perilaku syabab dan syababahnya yang berusaha keras untuk mengamalkan syariat Islam, dalam pandangan mereka. Inilah yang melandasi semangat mereka untuk menerapkan syariat Islam dan semangat untuk mendirikan khilāfah islämiyyah.

Ketiga, dalam batas-batas tertentu, spiritualitas HTI menemukan relevansinya di era modern, terutama dilihat dari kebutuhan untuk mengembangkan semangat intelektualisme ('aqliyyah) dan aktivisme (nafsiyyah). Namun demikian, spiritualitas Hizbut Tahrir tidak memberikan ruang yang cukup bagi kehangatan spiritual, yang sangat dibutuhkan oleh individuindividu modern yang semakin tercerabut dari akar primordialnya. Apalagi, HTI secara tegas menolak konsep spiritual sebagai dimensi terdalam dari kedirian manusia. Tetapi kekurangan atau kelemahan ini bisa dimaklumi, mengingat HTI memang menegaskan bahwa dirinya bukan lembaga kerohaian, seperti tarekat. Karena itu, HTI Jawa Tengah memberi kesempatan kepada shabāb dan shabābah-nya untuk mengasah dimensi ruhaniahnya di tempat lain, sepanjang tetap sejalan dengan pokok-pokok pikiran (mafāhim) yang dipedomani.

Terakhir, ada dua catatan penting yang ingin peneliti sampaikan dalam fenomena ini. Pertama, secara internal, HTI perlu melakukan kajian yang lebih sophisticated terhadap syariah Islam, termasuk di dalamnya spiritualitas sebagai pengembangan lebih lanjut dari dimensi ihsan. Sehingga ketenangan dan keteduhan batin yang didambakan oleh setiap insane akan mendapatkan salurannya. Itulah barangkali, sejumlah buku yang mengekplorasi masalahmasalah hati mulai diperbanyak. Kedua, secara eksternal, tampaknya di- 
butuhkan pemahaman yang lebih utuh terhadap HTI. Sehingga pihak-pihak yang selama ini berseberangan akan bias lebih memahami. Karena HTI sesungguhnya lebih banyak menyediakan kerangka atau wadah, dan isinya akan sangat tergantung kepada para shabāb atau shabābah yang terlibat.[w] 


\section{BIBLIOGRAFI}

Abdurrahman, Hafidz, Diskursus Islam, Politik dan Spiritual, Bogor: al-Azhar Press, 2004.

Agustian, Ary Ginanjar, ESQ (Emitonal Spiritual Quotient): Rahasia Sukses Membangun Kecerdasan Emosi dan Spiritual, Jakarta: Arga, 2001.

Bastaman, Hanna Jumhana, Meraih Hidup Bermakna, Jakarta: Paramadina, 1996.

Bruinessen, Martin van ,Tarekat Naqsyabandiyah di Indonesia, Bandung: Mizan, 1996.

Capra, Fritjof, Menyatu dengan Semesta, Yogyakarta: Fajar Pustaka Baru, 1991.

Cooper, Robert dan Ayman Sawaf, Executive EQ: Kecerdasan Emosional dalam Kepemimpinan dan Organisasi, Jakarta: Gramedia, 1997.

Covey, Stephen, 7 Kebiasaan Manusia yang Sangat Efektif, Jakarta: Bina Rupa Aksara, 1994.

Danim, Sudarwan, Menjadi Peneliti Kualitatif, Bandung: Pustaka Setia, 2002.

Hidayat, Komaruddin dan Ahmad Gaus AF (ed.), Islam, Negara dan Civil Society, Jakarta: Paramadina, 2005.

Hill, Peter C. and Ralph W. Hood, Measures of Religiousity, Birmingham: Religious Education Press, 1999.

Hizbut Tahrir, Pilar-pilar Pengokoh Nafsiyyah Islamiyyah, Jakarta: Tim HTI-Press, 2008.

Jisr, Syeikh Nadim, Para Pencari Tuhan, Bandung: Pustaka Hidayah, 1996.

Madjid, Nurcholish, Bilik-bilik Pesantren: Sebuah Potret Perjalanan, Jakarta: Paramadina, 1997.

Media Politik dan Dakwah, al-Wa ̈̈, No. 93 Tahun VIII, 1-31 Mei 2008. al-Wa ï, No. 94 Tahun VIII, 1-30 Juni 2008. al-Wa ï, No. 95 Tahun VIII, 1-31 Juli 2008. al-Wa ï, No. 96 Tahun VIII, 1-31 Agustus 2008. al-Wa ï, No. 97 Tahun VIII, 1-30 September 2008. 
Mudzhar, Atho, Pendekatan Studi Islam dalam Teori dan Praktek, Yogyakarta: Pustaka Pelajar, 1998.

Muhadjir, Noeng, Metodologi Penelitian Kualitatif, Yogyakarta: Rake Sarasin, 1996.

Murata, Sachiko dan William C. Chittick, Trilogi Islam: Islam, Iman dan Ihsan, Jakarta: Raja Grafindo Persada, 1997.

Nabhani, Syeikh Taqiyuddin, Pokok-pokok Pikiran Hizbut Tahrir, terjemahan Mafahim Hizbut Tahrir oleh Abu Afif, Jakarta: Pustaka Thariqul Izzah, 1993.

Nashr, Seyyed Hussein, Nestapa Manusia Modern, Bandung: Pustaka, 1995.

Pasiak, Taufiq, Revolusi IQ/EQ/SQ: Antara Neurosains dan al-Qur’an, Bandung: Mizan, 2003.

Putra, Yusdeka, Membuka Ruang Spiritual: Langkah per Langkah Perjalanan Mengenai Tuhan, Jakarta: Yayasan Shalat Khusyu', 2006.

Sugiyono, Memahami Penelitian Kualitatif, Bandung: Alfabeta, 2005.

Tasmara, Toto, Kecerdasan Ruhaniah: Membentuk Kepribadian yang Bertanggung Jawab, Profesional dan Berakhlak, Jakarta: Gema Insani Press, 2001. 
